\title{
Changes of Feeding Behaviors of Myzus persicae (Homoptera: Aphididae) Depending on Inflow Concentrations of Imidacloprid
}

\author{
Mi Ja Seo, Myong Ki Kang ${ }^{1}$, Beom Haeng $\mathrm{Jo}^{2}$, In Cheon $\mathrm{Hwang}^{2}$, Chul Jang ${ }^{2}$, Yong Man Yu and \\ Young Nam Youn* \\ Department of Applied Biology, College of Agriculture and Life Sciences, Chungnam National University, Daejeon, 305-764, Korea \\ ${ }^{1}$ Dongbu Hiteck. Daejeon, Korea \\ ${ }^{2}$ Central Research Institute, Kyung-Nong, Kyungbuk, Korea
}

\begin{abstract}
After treatment with imidacloprid, there were clear differences in the time to the first reaction of Myzus persicae among the concentrations treated. The time taken for the proboscis of the aphids to penetrate, during the recording plants increased as the imidacloprid concentration increased. Imidacloprid concentration inflow into a leaf was investigated using high-performance liquid chromatography, and the residues of the imidacloprid varied slightly with the different concentrations treated. However, the inflow rates of this insecticide into a leaf increased as the dipping times increased. Furthermore, it was shown that there was no relationship in inflow concentration between the concentrations and times of treatment. However, the concentration in the leaf differed according to the dipping time. Judging from the fact that the first reaction behavior against imidacloprid displayed at an inflow concentration of $0.32-0.35 \mathrm{mg} / \mathrm{L}$, we concluded that inflow concentrations causing the first reaction of the aphids to the insecticide were much lower than the concentration treated. The general feeding characteristics of the aphids indicated that xylem and/or phloem feeding behavior continued after a series of probing behaviors and stylet activity during the first $3 \mathrm{~h}$ from the start of EPG recording. After 90 min treatment with imidacloprid, feeding behavior over the next $30 \mathrm{~min}$ indicated a significant increase in the withdrawal of the stylet from the plant at all treated concentrations. Xylem and/or phloem feeding patterns were significantly decreased during this time. In particular, the proportion of xylem feeding differed according to the concentration of imidacloprid.
\end{abstract}

KEY WORDS : EPG, HPLC, Inflow concentration, Myzus persicae

초 록 : Imidacloprid를 처리한 후에 복숭아혹진딧물의 처음 반응은 처리농도에 따라 차이를 나타내고 있다. 복숭아혹진딧물의 구침이 식물체에 머무는 시간은 imidacloprid의 농도가 증가함에 따라서 증가하는 경향을 보였다. 잎에 침투한 imidacloprid의 농도는 HPLC를 이용하여 측정하였으며, imidacloprid가 잎에 잔류하고 있는 잔류량은 처리농도를 달리함에 따라서 약간의 차이를 나타내고 있다. 그렇지만, imidacloprid의 침투이행 비율은 침지시간이 길어질수록 높았으나, imidacloprid의 농도와 침지 시간사이의 잔류량은 상관관계가 없었다. 복숭아혹진딧물이 imidacloprid에 대하여 처음 반응하는 잔류량은 0.32-0.35 $\mathrm{mg} / \mathrm{L}$ 에서 볼 수 있었다. 따라서 아마도 복숭아혹진딧물은 imidacloprid의 추천 농도보다 매우 적은 량을 처리하더라도 인식할 것으로 생각된다. 복숭아혹진딧물은 $\mathrm{EPG}$ 기록을 시작하고 처음 3 시간 동안 활발한 기주탐색행동을 한 후에 물관부와 체관부에서 흡즙행동을 보이고 있다. Imidacloprid를 처리한 후 90 분 후부터 30 분간 진딧물이 구침을 식물체로부터 빼는 행동이 늘어나게 되며, 물관부 혹은 체관부에서 의 흡즙행동은 현저히 감소하게 된다. 특히 물관부에서의 흡즙하는 행동의 비율은 imidacloprid의 처리농도 에 따라서 매우 달라지게 된다.

검색어 : $\mathrm{EPG}, \mathrm{HPLC}$, 침투이행농도, 복숭아혹진딧물

*Corresponding author. E-mail: youngnam@enu.ac.kr 
The green peach aphid, Myzus persicae (Sulzer), is a major pest worldwide that directly damages a wide range of economically important crop plants, and indirectly acts as a vector of plant viruses. It sucks plant sap during the whole developmental period of crops, causing seedling death, leaf curl and wither, and serious yield loss. Recently, imidacloprid, which belongs to the class of neonicotinoids, has been used one of the main insecticides for the control the green peach aphid.

Neonicotinoid insecticides were introduced into the market in the early 1990s, and are today one of the most important chemical groups used to control sucking insects (Nauen et al., 1995). Previous research have indicated low toxicity of these insecticides to adult females of several species of predatory phytoseiid mites such as: Neoseiulus collegae, Proprioseiopsis mexicanus, and Phytoseiulus macropilis (Mizell and Sconyers, 1992); Amblyseius womersleyi (Leicht, 1993); Typhlodromus doreenae and T. dossei (James and Vogele, 2001); and Amblyseius cucumeris (Kim et al., 2005). Similar action has been observed against predatory ladybirds such as Harmonia axyridis (Youn et al., 2003). Therefore, this insecticide has been intensively used to control many insect pests in various crops. Imidacloprid has insecticidal activity against insect pests by interfering with the transport of external neurotransmission stimulations and acetylcholine receptors. As a result, temporary paralysis or knockdown effects owing to contact with or ingestion of the chemical have been shown. The insects, however, might survive this treatment and their feeding behavior eventually restored.

It is difficult to observe the phytophagous insect having the feeding behavior of piercing sucking. An electrical penetration graph (EPG) technique forms an acceptable and well-established alternative to visual observation. The EPG technique has been used extensively in studies of aphid feeding behavior (McLean and Kinsey, 1964; Tjallingii, 1988; Prado and Tjallingii, 1994) and in other piercing sucking insects such as the brown planthopper (Youn, 1998; Seo et al., 2005). When feeding in phloem, the aphid stylet penetrates between the epidermal and mesophyll cells overlying the vascular tissues of the phloem until a suitable nutritional site is found (Sauge et al., 2002). Some aphid species initiate feeding by touching their proboscis to the plant surface, salivating, and then sucking back some fluid. This provides an opportunity to sample surface chemicals (Hashiba and Misawa, 1969). Thus, aphids determine whether a plant is suitable for feeding after several probing attempts.

When these aphid feeding behaviors were investigated using the EPG technique, aphid host searches and preferences were chemically mediated and involved chemoreception, which was likely due to secondary plant metabolites and an inflow of other chemicals. In particular, the feeding behavior of aphids might be changed by exposure to an inflow of insecticide through plant tissues from root and/or leaf cells during sucking behavior. On the nature of the mode of action of imidacloprid, it is difficult to induce the inhibition of direct feeding. As a result, it is impossible to control aphids effectively. Even so, if usage and concentration of imidacloprid were decreased, it might be difficult to inhibit aphids from feeding. From a commonsense point of view, when the aphids come into contact with the insecticide when feeding on leaves, they would avoid them and stop their sucking behavior. Therefore, it is possible to analyze their feeding behavior by monitoring the electrical signal caused by the inflow of chemicals. We have investigated how the feeding behavior patterns of aphids changed when the stylet makes contact with these chemicals using the EPG technique. In addition, imidacloprids were systemically applied to excised radish leaves, and their concentrations were measured through high-performance liquid chromatography (HPLC) analysis. Inflow concentration and systemic timing might change the practical feeding behavior of $\mathrm{M}$. persicae.

\section{Materials and Methods}

\section{Plants and insects}

The experimental host plants used for investigating feeding behavior were 57-week-old radishes (Raphanus sativus var. longipinnatus). The petiole of each radish leaf was cut and fixed with absorbent cotton to the inlet 
of a flask. The green peach aphids were reared on radishes under laboratory conditions (Temp.: 23 2C, RH: 5065\%); apterous adult aphids collected from these radishes were used in this experiment. The experimental conditions were similar to the rearing conditions.

\section{Electrical penetration graphs}

Electrical penetration graphs were recorded from apterous adults, 23 days after molting, using the DC methods of Tjallingii (1988). Before EPG recording, each aphid was attached to a gold wire $(4 \mathrm{~cm}$ long, $25 \mu \mathrm{m}$ diameter, Goodfellow, UK) with silver conductive paint (RS, 101-5621, UK), and placed on a test leaf. The end of the gold wire was connected to an amplifier (MOD.P122, GRASS Ins., Astro-Med Inc., USA). When the proboscis of the aphid was initially lowered to the cuticle surface, observations began. When the proboscis penetrated the plant cuticle, an electrical circuit was completed, producing waveforms recorded by a chart recorder (DASH IV, Astro-Med. Inc.). Before the recordings, all tested aphids were starved in Petri dishes for $1 \mathrm{hr}$.

\section{Imidacloprid treatments and electrical recordings of feeding behavior}

After $1 \mathrm{hr}$ of recording from the initiation of probing by the green peach aphid, three diluted solutions of imidacloprid were added to flasks. This was after taking into consideration the volume of water they held. The solutions were the recommended concentration (50 $\mathrm{mg} / \mathrm{L}), 20 \%$ recommended $(10 \mathrm{mg} / \mathrm{L})$, and five times recommended $(250 \mathrm{mg} / \mathrm{L})$. The time period required for the aphids to come into contact with the pesticide through their stylets and changes in stylet penetration by treatment of imidacloprid were investigated. EPG signals were monitored over $7 \mathrm{hrs}$ and the aphids were checked regularly. The characteristic patterns of feeding behaviors investigated were as follows: 1) total non-probing times (np), 2) total phloem feeding time (phloem), 3) total xylem feeding time (xylem), 4) total pathway activity time, and 5) the time taken until stylet activities changed after treatment with imidacloprid (when aphid stylets were withdrawn from the plant, thereby cutting off the electrical signals, or when stylet activities differed from signal patterns before the treatment).

\section{High-performance liquid chromatography analysis}

The ends of radish leaf petioles were dipped in the diluted imidacloprid solution $(10,50$, and $250 \mathrm{mg} / \mathrm{L})$ for $0.5,1,1.5$, and $2 \mathrm{hrs}$, after which the portion of the petiole directly in contact with the diluted solution was removed. To estimate the inflow concentration of the insecticide, the mass of each leaf tested was measured. Five grams of tested leaf was diluted with $100 \mathrm{ml}$ acetone and the mixture was shaken for $1 \mathrm{hr}$. Dichloromethane was added, and then a dehydration procedure using sodium sulfate was repeated. Samples were injected onto a Shiseido column and separated using the mobile phase (water/acetonitrile, 75/25). The column temperature was maintained at 30C. Extraction samples were analyzed by HPLC with UV detection at $270 \mathrm{~nm}$ (Agilent 1100 series).

\section{Statistical analysis}

Data on all of the EPG parameters obtained from each experiment were analyzed using a completely randomized one-way analysis of variance (ANOVA) at $\mathrm{P}<0.05$. Differences among treatments were then compared using Scheffe's post hoc test HSD. All statistical tests were conducted with SPSS software (SPSS, Chicago, IL, USA).

\section{Results}

Four feeding behavioral patterns were monitored for $1 \mathrm{hr}$, from the start of EPG recording to treatment with each concentration of the insecticide (Fig. 1). All four feeding patterns were observed during the early period of recording. After stylet pathway activities (PA) were exhibited, phloem and/or xylem feeding pathways were mainly observed. However, the proportion of feeding patterns did not differ, regardless of the concentration of the insecticide (Nonpenetration (NP): $\mathrm{df}=3, \mathrm{~F}=0.614$, $\mathrm{P}=0.609$; PA: df $=3, \mathrm{~F}=1.388, \mathrm{P}=0.257$; Xylem: 
$\mathrm{df}=3, \mathrm{~F}=1.114, \mathrm{P}=0.352 ;$ Phloem: $\mathrm{df}=3, \mathrm{~F}=$ 0.433, $\mathrm{P}=0.730)$.

The proportion of each feeding behavior from $30 \mathrm{~min}$ after treatment with the insecticide indicates that as feeding progressed over $1 \mathrm{hr}$ (60-90 min after insecticide application), patterns related to xylem and/or phloem feeding were mainly observed (Fig. 2). However, such feeding patterns did not differ, regardless of the concentration of the insecticide. Moreover, no differences were noted in the proportions of each feeding behavior with insecticide concentration (NP: $\mathrm{df}=3, \mathrm{~F}=0.447$, $\mathrm{P}=0.720$; PA: df $=3, \mathrm{~F}=1.614, \mathrm{P}=0.198 ;$ Xylem: df $=3, F=0.232, P=0.874$; Phloem: $\mathrm{df}=3, \mathrm{~F}=$ $0.221, \mathrm{P}=0.881)$. This may indicate that that the insecticide was not taken up by the leaves into aphid feeding sites at concentrations that affected aphid feeding behavior.

Imidacloprid taken up by the leaves 90-120 min after application had no effect on feeding behavior of the green peach aphids until $1 \mathrm{hr}$ after treatment (Fig. 3). The duration of NP behavior increased in this time range, but no difference was noted among the treated pesticide concentrations (NP: $\mathrm{df}=3, \mathrm{~F}=0.609, \mathrm{P}=0.612$; PA: df $=3, F=0.753, P=0.526$; Xylem: $d f=3, F=0.824$, $\mathrm{P}=0.487$; Phloem: $\mathrm{df}=3, \mathrm{~F}=0.066, \mathrm{P}=0.978$ ).

During the next $30 \mathrm{~min}$ (120-150 min after application), the proportions of phloem and/or xylem feeding behavior generally decreased, while that of stylet withdrawal (NP) behavior increased significantly (Fig. 4). At this point, aphids had responded to the imidacloprid that had reached the aphid feeding site in the leaf tissues. In the four feeding behavior patterns examined, only the proportion

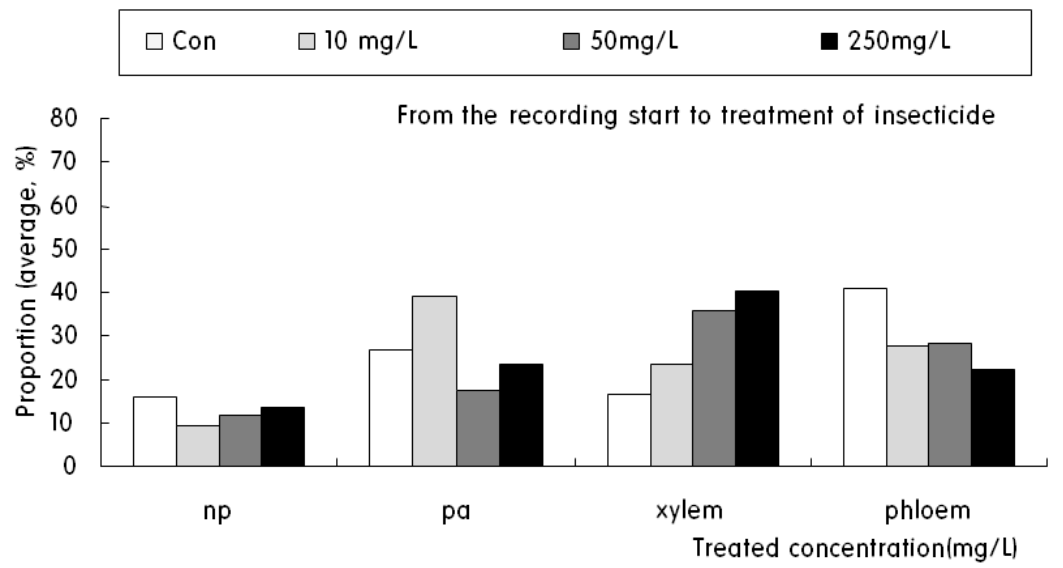

Fig. 1. Proportion (average percentage of duration) of feeding pattern behaviors according to the treated concentrations for $1 \mathrm{hr}$ before insecticide application. np: non-probing; pa: stylet pathway activity.

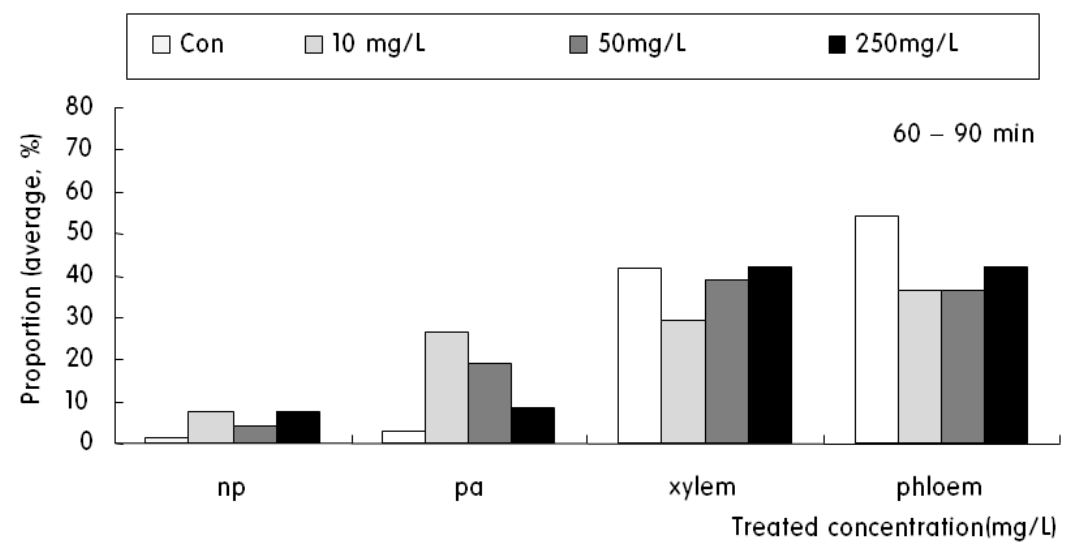

Fig. 2. Proportion (average percentage of duration) of feeding pattern behaviors from 60 to 90 min after the insecticide treatments had been applied for 30 min. np: non-probing; pa: stylet pathway activity. 


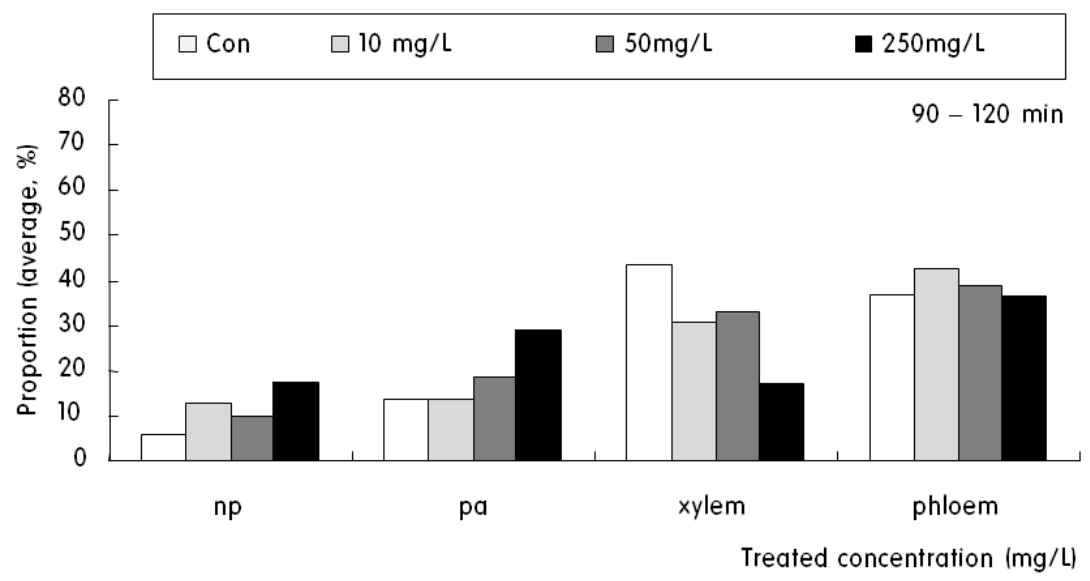

Fig. 3. Proportion (average percentage of duration) of feeding pattern behaviors from 90 to 120 min after the insecticide treatments had been applied for $30 \mathrm{~min}$. np: non-probing; pa: stylet pathway activity.

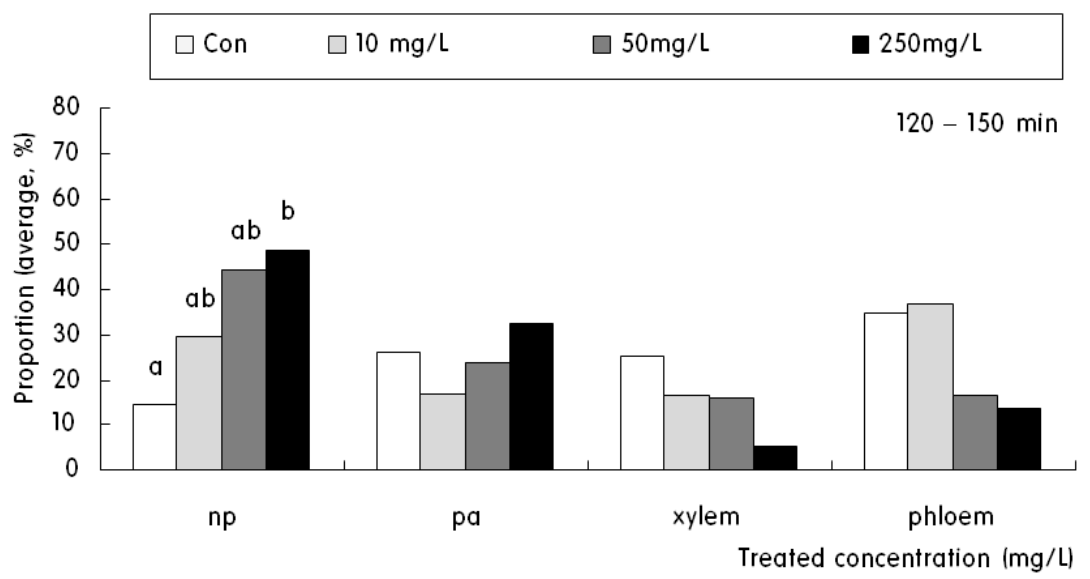

Fig. 4. Proportion (average percentage of duration) of feeding pattern behaviors 120-150 min after the insecticide treatments had been applied for $30 \mathrm{~min}$. np: non-probing; pa: stylet pathway activity.

of non-probing behavior changed to response to insecticide concentration. At the treatment of $250 \mathrm{mg} / \mathrm{L}$, the highest dose, inhibition of feeding behavior (NP) in this time period indicated withdrawal of about $50 \%$ of aphid stylets (df $=3, F=2.029, P=0.121)$. However, there was no difference in the other three feeding patterns (PA: df $=$ $3, \mathrm{~F}=0.683, \mathrm{P}=0.567$; Xylem: $\mathrm{df}=3, \mathrm{~F}=1.095, \mathrm{P}$ $=0.360$; Phloem: $\mathrm{df}=3, \mathrm{~F}=1.902, \mathrm{P}=0.141$ ).

Investigation of the feeding patterns during this period indicated that stylet withdrawal frequency had increased significantly at all imidacloprid concentrations $(\mathrm{df}=3$, $\mathrm{F}=4.529, \mathrm{P}=0.007)$. Compared with the results in the prior period, xylem and/or phloem feeding behavior were significantly decreased. In particular, the proportion of xylem feeding varied with insecticide concentration $(\mathrm{df}=3, \mathrm{~F}=1.963, \mathrm{P}=0.131)$. The insecticide taken up by the leaves likely had reached a threshold concentration that affected aphid feeding from $90 \mathrm{~min}$ after treatment (PA: df $=3, \mathrm{~F}=0.143, \mathrm{P}=0.933$; Phloem: $\mathrm{df}=3, \mathrm{~F}=1.392, \mathrm{P}=0.256$ ) (Fig. 5).

During the 420 min of EPG recordings from set up, the feeding behaviors of the green peach aphid were analyzed using three types of EPG parameters: nonfeeding, phloem feeding, and pathway activity time. When aphids were exposed to the leaves treated with systemic insecticide, their stylets withdrew, their proboscis did not penetrate the plant cuticles, and the electrical circuit was not completed. The duration at which the proboscis of the aphids did not penetrate the plant during the recording increased as the imidacloprid concentration increased (df 


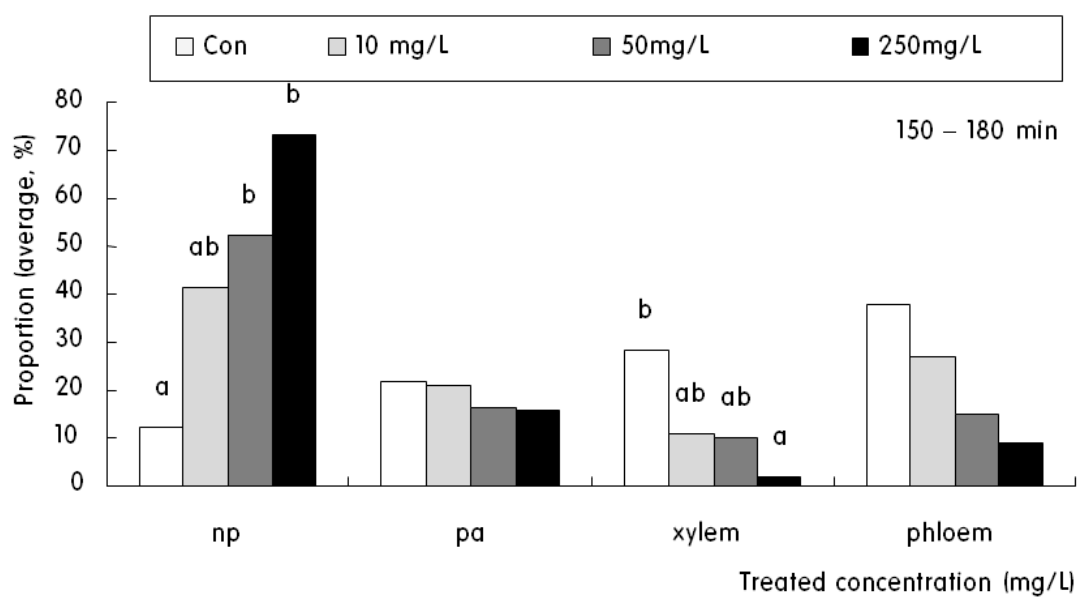

Fig. 5. Proportion (average percentage of duration) of feeding pattern behaviors 150-180 min after the insecticide treatments had been applied for $30 \mathrm{~min}$. np: non-probing; pa: stylet pathway activity.

Table 1. The EPG parameters that recorded probing behavior of $M$. persicae on radish leaves treated with imidacloprid over 420 min ${ }^{\mathrm{a}}$

\begin{tabular}{cccccc}
\hline & \multicolumn{4}{c}{ Imidacloprid concentrations } \\
\cline { 2 - 5 } EPG parameters & $250 \mathrm{mg} / \mathrm{L}$ & $50 \mathrm{mg} / \mathrm{L}$ & $10 \mathrm{mg} / \mathrm{L}$ & \multicolumn{2}{c}{ Control $^{\text {Significance }}$} \\
& $\mathrm{n}=13$ & $\mathrm{n}=13$ & $\mathrm{n}=13$ & $\mathrm{n}=10$ & level $^{\mathrm{b}}$ \\
\hline Duration of non-penetration $(\mathrm{min})$ & $281.77 \pm 25.1 \mathrm{c}$ & $272.4 \pm 71.9 \mathrm{bc}$ & $212.6 \pm 58.8 \mathrm{~b}$ & $27.4 \pm 28.7 \mathrm{a}$ & $0.000^{* *}$ \\
Total phloem ingestion time (min) & $0.4 \pm 1.5 \mathrm{a}$ & $25.5 \pm 28.3 \mathrm{~b}$ & $19.9 \pm 17.9 \mathrm{ab}$ & $26.7 \pm 24.7 \mathrm{~b}$ & $0.009^{*}$ \\
Total pathway activity time (min) & $91.0 \pm 34.5 \mathrm{a}$ & $100.2 \pm 49.8 \mathrm{a}$ & $94.7 \pm 19.8 \mathrm{a}$ & $122.7 \pm 81.0 \mathrm{a}$ & $0.444^{\mathrm{NS}}$ \\
\hline
\end{tabular}

${ }^{a}$ Values represent mean SD. Different letters at values in rows show significant differences (one-way ANOVA, post hoc tests by Scheffe) in SPSS Version 12.0.

b ${ }^{*}$ indicates $P<0.05,{ }^{* *} P<0.01$, and NS $P>0.05$.

$=3, \mathrm{~F}=57.028, \mathrm{P}=0.000$ ) (Table 1). In the untreated control for the $420 \mathrm{~min}$ of recording, it was noted that the aphids withdrew their stylets and then stopped to feed temporarily or searched for new feeding sites on the leaf for about $27 \mathrm{~min}$. Conversely, in the imidacloprid treatment, the aphids spent over half of the total recording time searching for a suitable feeding site. Thus, the proboscis of the aphids did not penetrate the leaves for over $200 \mathrm{~min}$ in the three insecticide treatments. Aphid feeding patterns changed after uptake of the insecticide solution through their mouthparts. Second, the investigation of phloem feeding duration in $250 \mathrm{mg} / \mathrm{L}$ imidaclopridtreated leaves, indicated that almost all tested aphids ingested phloem sap within only $1 \mathrm{~min}$. The expected main effect of treatment of a leaf with imidacloprid was a typical, strongly reduced duration of phloem feeding. In our results, there was a slightly different duration of phloem feeding among the imidacloprid concentrations examined ( $\mathrm{df}=3, \mathrm{~F}=4.381, \mathrm{P}=0.009$ ). By contrast, measurements of stylet activity times (PA) during leaf penetration toward phloem elements, no significant differences were found among the three insecticide concentrations $(\mathrm{df}=3, \mathrm{~F}=0.910, \mathrm{P}=0.444)$.

Table 2 shows the results of the first reaction time and the frequency of electrical contact signals after treatment with imidacloprid. The addition of imidacloprid solution to radish leaves caused a significant change in the probing behavior of the aphids. The most active reaction expressed by the aphids was the withdrawal of the proboscis and disconnection of the electrical circuit. In our study, this pattern was termed the first reaction, and the time taken to reach it was measured to estimate the response to the insecticides. Practically, if aphids come into contact with the insecticide solutions taken up by leaves, they stop feeding and withdraw their proboscis from the plant. However, with time, they try to feed once more and so risk the chance of coming into contact with the insecticides again. This pattern is 
repeated, and although aphids will normally feed at lower concentrations, it is suggested that there is no disruption to probing and the aphids will continue to feed on the treated leaves. However, if the leaves inflowed higher concentrations of insecticide, feeding attempts by the aphids are more repeated and eventually they will not be able to sustain their feeding behaviors. Our results indicate clear differences in the time of the first reaction against imidacloprid among the concentrations treated. At the $250 \mathrm{mg} / \mathrm{L}$ treatment of imidacloprid, after 43.5 min (the mean time) of recording, the aphid proboscis was withdrawn. At $10 \mathrm{mg} / \mathrm{L}$, the mean time to the first reaction was about $113.8 \min (\mathrm{df}=3, \mathrm{~F}=49.840, \mathrm{P}$ $=0.000$ ). After the first reaction, the feeding trial times were about 8.8 times at $250 \mathrm{mg} / \mathrm{L}$ and 3.8 times at 10 $\mathrm{mg} / \mathrm{L}$. Therefore, there was a significant difference among the concentrations examined $(\mathrm{df}=3, \mathrm{~F}=7.193$,
$\mathrm{P}=0.000)$.

Table 3 shows the correlations between the insecticide concentration inflowed into a leaf and the first reaction time by aphids investigated according to dipping time. There was a slight difference in inflow concentration with the concentration of the insecticide. However, in general, the concentration of insecticide taken up by a leaf increases with dipping time. Results indicated that at all three insecticide concentrations, the first reaction (aphid stylets withdrawn from the leaf) occurred when 0.32-0.35 $\mathrm{mg} / \mathrm{L}$ imidacloprid remained in a leaf. Moreover, there was a similarity between the first reaction time against insecticide and dipping time at the remaining concentration showing the first reaction.

HPLC analyses indicated that there was no relationship between the residual concentration of imidacloprid in leaves and the concentration taken up and time $(\mathrm{df}=$

Table 2. First reaction time ${ }^{\mathrm{a}}$ and the frequency of electrical contact signals ${ }^{\mathrm{b}}$ after treatment with imidacloprid ${ }^{\mathrm{c}}$

\begin{tabular}{|c|c|c|c|c|c|}
\hline \multirow{2}{*}{ EPG parameters } & \multicolumn{4}{|c|}{ Imidacloprid concentrations } & \multirow{2}{*}{$\begin{array}{c}\text { Significance } \\
\text { level }^{c}\end{array}$} \\
\hline & $250 \mathrm{mg} / \mathrm{L}$ & $50 \mathrm{mg} / \mathrm{L}$ & $10 \mathrm{mg} / \mathrm{L}$ & Control & \\
\hline First reaction time & $43.5 \pm 11.7 \mathrm{a}$ & $66.3 \pm 17.7 b$ & $113.8 \pm 18.0 \mathrm{c}$ & - & $0.000^{* *}$ \\
\hline The frequency of electrical contact & $8.8 \pm 6.7 \mathrm{~b}$ & $3.6 \pm 2.8 \mathrm{ab}$ & $3.8 \pm 4.3 \mathrm{ab}$ & $0.5 \pm 0.7 \mathrm{a}$ & $0.000^{* *}$ \\
\hline
\end{tabular}

Table 3. The mean time to the first reaction and the inflowed concentration ${ }^{\mathrm{a}}$ of imidacloprid in a leaf at each concentration

\begin{tabular}{cccc}
\hline & $250 \mathrm{mg} / \mathrm{L}$ & $50 \mathrm{mg} / \mathrm{L}$ & $10 \mathrm{mg} / \mathrm{L}$ \\
\hline The first reaction (min) & $43.5 \pm 11.7 \mathrm{a}$ & $66.3 \pm 17.7 \mathrm{~b}$ & $113.8 \pm 18.0 \mathrm{c}$ \\
The inflow of imidacloprid & $0.25 \sim 0.47(0.35 \pm 0.11)$ & $0.27 \sim 0.48(0.34 \pm 0.12)$ & $0.22 \sim 0.43(0.32 \pm 0.40)$ \\
in a tested leaf & $(0.5 \mathrm{hr})$ & $(1.0 \mathrm{hr})$ & $(1.5 \mathrm{hr})$ \\
\hline
\end{tabular}

${ }^{\mathrm{a}}$ Residue concentration was measured by HPLC.

${ }^{b}$ Letters $(a, b$ and $c)$ indicate significant differences $(F=49.840 ; P=0.000$ : completely randomized one- way analysis of variance, ANOVA, post hoc tests by Scheffe).

${ }^{\mathrm{c}}$ Values in parentheses indicate the mean inflow concentration $(\mathrm{mg} / \mathrm{L})$ and the dipping time $(\mathrm{hr})$ of the petiole of a leaf tested.

Table 4. Two-way ANOVA for testing significance in imidacloprid concentration inflowed into a leaf (mg/L) and for investigating the presence of interactions between time and the concentration of dipping

\begin{tabular}{ccccc}
\hline Source of variation & df & MS & F & P \\
\hline Time & 3 & 0.757 & 7.314 & $0.001^{* *}$ \\
Concentration & 2 & 0.504 & 4.871 & $0.017^{*}$ \\
Time concentration & 6 & 0.152 & 1.464 & $0.232^{\mathrm{NS}}$ \\
\hline
\end{tabular}

${ }^{*} p<0.05 ;{ }^{* *} p<0.001 ;{ }^{\mathrm{NS}} p>0.05$. 
$3, \mathrm{~F}=1.464, \mathrm{P}=0.232$ ). A leaf dipping time of the excised radish leaf petioles, however, did affect the concentration taken up by leaves. The concentration inflowed into a leaf was significantly affected from 1.5 $\mathrm{hr}$ after dipping at all three insecticide concentrations, especially at $250 \mathrm{mg} / \mathrm{L}$ and $50 \mathrm{mg} / \mathrm{L}$. At the lowest concentration $(10 \mathrm{mg} / \mathrm{L})$, however, the concentration taken up was reduced after $1.5 \mathrm{hr}$.

\section{Discussion}

Using the EPG technique, our study showed that the imidacloprid inflowed into excised radish leaves changed the feeding behavior of the green peach aphids. Although many studies have shown aphid responses to imidacloprid and its lethal concentrations, many aspects of aphid behavior in response to imidacloprid have not been widely investigated. When lethal concentrations of this insecticide are used to control aphids, dose concentrations and the number of field applications may increase. This is because selection pressure would lead to the appearance of aphids resistant to the insecticide. Imidacloprid showed effects on $M$. persicae at low concentrations, which included a reduction of honeydew excretion, loss of weight, restless behavior, and moving from treated to untreated leaves. This illustrates the considerable antifeeding properties of this compound (Nauen, 1995). EPG recordings showed that $M$. persicae probed for shorter durations (total probing time) on leaves systemically treated with imidacloprid than on untreated leaves. Naeun et al. (1995) suggested that imidacloprid acted as a repellent or antifeedant against $M$. persicae rather than as an insecticide.

In addition, in our results, comparing the total time of NP to the concentration treated, it was shown that the time increased with an increase in the imidacloprid concentration. However, the fact that the NP time was longer in the higher concentration treatments of imidacloprid compared with the lower concentration treatments certainly does not reflect an antifeedant response. Results from the electrical contact signals indicated that the frequency of penetration attempts was over 8.8 on average at high concentration $(250 \mathrm{mg} / \mathrm{L})$, indicating that this insecticide appears to have a temporary antifeeding effect at sublethal concentrations. However, such a feeding inhibition could not be continuously maintained. Despite this, these antifeeding properties would eventually affect the fecundity and survival of aphids as repeated penetration attempts would starve the aphids over time. While other insecticides such as azinphosmethyl have been reported to cause increased fecundity in aphids at certain concentrations, low concentrations of imidacloprid have been shown to inhibit the production of larvae of $M$. persicae (Gorden and McEwen, 1984; Lowery and Sears, 1986). Some results have indicated that sublethal doses of imidacloprid might show low lethal effects against target insect pests. However, the insecticide shows promise because it is able to maintain the population of insect pests at low levels at low doses and to thereby reduce damage to the environment, humans, and animals. In addition, it is moderately safe to the natural enemies of the target pests. Hence, it would be useful in integrated pest management (IPM). Youn et al. (2003) suggested that direct exposure to imidacloprid caused significant mortality to eggs and early instars of $H$. axyridis. As such, the high toxicity of this insecticide for younger stages of $\mathrm{H}$. axyridis indicates that foliar spray applications of this chemical must be considered carefully for use in IPM programs. It was shown in this study that the effect of treatment of excised radish leaves with imidacloprid definitely reduced the duration of phloem feeding. Therefore, it is considered that the feeding behavior of the aphids was disturbed at a high concentration of imidacloprid $(250 \mathrm{mg} / \mathrm{L})$. It is possible that imidacloprid affects the plant itself in such a way that the quality of the phloem sap changes due to alterations in the amino acid composition, which could also inhibit ingestion by the aphids. Ponder et al. (2000) reported that on nitrogen-deficient plants, aphids spent a greater proportion of time failing to penetrate tissues (increased NP) and spent less time in phloem ingestion. In spite of these interesting behavioral effects of imidacloprid on M. persicae at sublethal concentrations, it is not possible to reduce the recommended field rates, because long-term 
field studies, resistance management strategies, and the different dose-response characteristics of pests in the spectrum covered by imidacloprid have to be taken into consideration (Nauen et al., 2001).

We also investigated the correlation between the concentration inflowed into a leaf and the first reaction time of aphids. In our results, the first reaction behavior was that the proboscis of the aphids was withdrawn from the leaves at imidacloprid inflow concentrations of 0.32-0.35 mg/L. However, when the recommended concentration $(50 \mathrm{mg} / \mathrm{L})$ was applied, the concentration at which the first reaction was observed remained in the leaves after $1 \mathrm{hr}$ of treatment. Unexpectedly, the inflow concentration of imidacloprid that caused the first reaction in the green peach aphid was much lower than the treatment concentration. Furthermore, there might be a clear difference between foliar and soil treatments in the concentration inflowed into a plant. Our results similarly showed that feeding attempts were sustained after the first reaction was observed, but feeding behavior did not normally occur. On the other hand, despite treatment with a low concentration of insecticide, as time passed, inflow concentrations increased. This would affect the feeding behavior of the green peach aphid.

In the case of pymetrozine, direct contact resulted in an almost immediate block of the initiation of new probes. Lower dosages resulted in reduced probe initiations, but the aphids approached the veins where they normally feed, suggesting that there was no disruption to feeding site location (Harrewijn and Kayser, 1997). Pirimicarb also showed no significant behavioral changes to $M$. persicae at low concentrations (Nauen, 1995). After topical administration of recommended field doses of imidacloprid, aphids show symptoms typical for compounds interfering with the insect nervous system, such as uncoordinated movement, paralysis, and tremor (Leicht, 1993). Apart from the clearly visible effects on the insect nervous system, other authors have described some behavioral effects, mainly on aphids. With our results, it was observed that inflow levels of insecticides and the reaction of insect pests against insecticides were contrary to our expectations. Consequently, through the investigation of many insecticides including imidacloprid that are widely used to control insect pests using the methods described above, effective crop protection against various insect pests will be expected to be accomplished in the field.

\section{Acknowledgements}

This study was financially supported by the Agricultural R\&D Promotion Center (ARPC) in 2008.

\section{Literature Cited}

Gorden, P.L. and F.L. McEwen. 1984. Insecticide-stimulated reproduction of Myzus persicae, the green peach aphid (Homoptera: Aphididae). Can. Entomol. 116: 783-784.

Harrewijn, P. and H. Kayser. 1997. Pymetrozine, a fast-acting and selective inhibitor of aphid feeding. In-situ studies with electronic monitoring of feeding behavior. Pestic. Sci. 49: 130-140.

Hashiba, T. and T. Misawa. 1969. Studies on the mechanism of aphid transmission of stylet-borne virus III. On the adherence of the virus to the stylet. Tohoku J. Agri. Res. 20: 159-171.

James, D.G. and B. Vogele. 2001. The effect of imidacloprid on survival of some beneficial arthropods. Plant Protect Quart 16: 58-62.

Kim, S., S. Seo, J.D. Park. S.G. Kim,. and D.I. Kim. 2005. Effects of selected the predatory mite, Amblyseius cucumeris (Acari: Phytoseiidae). J. Entomol. Sci. 40: 107-114.

Leicht, W. 1993. Imidacloprid-a chloronicotinyl insecticide. Pest Outlook 4: 1724.

Lowery, D.T. and M.K. Sears. 1986. Stimulation of reproduction of the green peach aphid (Homoptera: Aphididae) by azinphosmethyl applied to potatoes. J. Econ. Entomol. 79: 1530-1533.

McLean, D.L. and M.G. Kinsey. 1964. A technique for electrically recording aphid feeding and salivation. Nature 202: 1358-1359.

Mizell, R.F. and M.C. Sconyers. 1992. Toxicity of imidacloprid to selected arthropod predators in the laboratory. Florida Entomol. 75: 277-280.

Nauen, R. 1995. behavior modifying effects of low systemic concentrations of imidacloprid on Myzus persicae with special reference to an antifeeding response. Pestic. Sci. 44: 145-153.

Nauen, R., U. Ebbinghaus-Kintscher, A. Elbert, P. Jeschke, K. Tietjen. 2001. Acetylcholine receptors as sites for developing neonicotinoid insecticides. In: Ishaaya, I. (ed.), Biochemical Sites of Insecticides Action and Resistance. Springer, New York, pp. 77-105.

Ponder, K.L., J. Pritchard, R. Harrington and J.S. Bale. 2000. Difficulties in location and acceptance of phloem sap combined with reduced concentration of phloem amino acids explain lowered performance of the aphid Rhopalosiphum padi on nitrogen deficient barley (Hordeum vulgare) seedlings. Ent. Exp. Appl. 97: 203-210.

Prado, E. and W.F. Tjallingii. 1994. Aphid activities during sieve 
element punctures. Ent. Exp. Appl. 72: 157-165.

Sauge, M.H., J.P. Lacroze, J.L. Poessel, T. Pascal and J. Kervella. 2002. Induced resistance by Myzus persicae in the peach cultivar 'Rubira'. Ent. Exp. Appl. 102: 29-37.

Seo, M.J., J.K. Jang, E.J. Kang, M.K. Kang, N.S. Kim, Y.M. Yu, Y.N. Youn. 2005. Feeding behavior in the plant tissues with green peach aphid (Myzus persicae, Aphididae; Homoptera) using EPG technique. Kor. J. Appl. Entomol. 44: 271-276.

Tjallingii, W.F., 1988. Electrical recording of stylet penetration activities by aphids. In: Campbell, R.K. Eikenbary, R.D. (eds.), Aphid-Plant Genotype Interactions. Elsevier, Amsterdam. pp. 89-99.

Youn, Y.N. 1998. Electrically recorded feeding behavior of Nephotettis cincticeps. J. Asia-Pac Entomol. 1: 147-161.

Youn, Y.N. M.J. Seo, J.G. Shin, C. Jang, and Y.M. Yu. 2003. Toxicity of greenhouse pesticides to multicolored Asian lady beetles, Harmonia axyridis (Coleoptera: Coccinellidae). Biol. Control 28: 164-170.

(Received for publication November 27 2008;

revised November 27 2008; accepted December 3 2008) 